\title{
CORRUPTION AND SOCIAL WELFARE IN THE EU27 COUNTRIES
}

\author{
Mihai Mutaşcu ${ }^{1}$ \\ Dan Constantin Dănulețiu ${ }^{2}$
}

\begin{abstract}
The corruption is a complex and generalized phenomenon all over the world, with cultural, social, psychological, political and economical dimensions. The defining and the studying of the phenomenon are going through the most different thinking filters known in the specialized literature: social-cultural, political, administrative and economic. The article's aim is to quantify and analyze the relationship between corruption and political, administrative and economic determinants factors, through a regressive "pool data" model. The sample includes the 27 countries of the actual European Union, and the data refer to the period 1996-2008. The study shows that the limitation of corruption's phenomena (maximizing FC index) has the result of increasing of social welfare (maximizing HDI index).
\end{abstract}

Keywords: corruption, social welfare, EU27

JEL codes: D73, I30

\section{Introduction}

The corruption is a complex and generalized phenomenon all over the world, with economical, cultural, social, psychological, political, administrative and religious dimensions. By consequence, defining and the studying of the phenomenon are going through the most different thinking filters known in the specialized literature: economic, social-cultural, political, administrative and religious. Its conceptualization has attracted in recent past competing and numerous views and approaches. Nye(Nye, 1967) defined corruption as a behavior which deviates from the formal duties of a public role because of private-regarding (personal, close family, private clique) pecuniary or status gains; or violates rules against the exercise of certain types of privateregarding influence and he included in this category bribery, nepotism and misappropriation.

In the economic approach, the government controls the distribution of revenues and the taxation of onerous costs. The private individuals and firms, in such context, tend to receive the advantages from public authority. If the "payment for advantages" is illegal, then we can talk about corruption. Seen as a transaction between private and public sector actors, the effect of corruption is the tendency to convert illegitimately collective goods into private regarding payoffs (Heidenheimer et. al., 1993). In other words, Mauro saw corruption as an extra tax which leaves less money for public expenditures (Mauro, 1997). Tanzi sustain this opinion and suggest that corruption transfers resources from the mass public to the elites - and generally from the poor to the rich (Tanzi, 1998). But the most widespread definition regards corruption as a misuse of public power for private gain (Rose-Ackerman, 1999). According to Rose-Ackerman, the corruption is a symptom for the situations in which the management of the state is inefficient.

The consequences of corruption on economic growth it is perceived to be negative, but a series of studies was conducted in order to find that this perception is correct or not. Based on this understanding, this paper intends to clarify the relationship between corruption and social welfare.

\footnotetext{
1 West University of Timisoara, Faculty of Economics and Business Administration, Pestalozzi 16, Timisoara, e-mail: mmutascu 74@yahoo.com

2 “1 Decembrie 1918” University Alba Iulia, e-mail: dan.danuletiu@gmail.com
} 


\section{Literature review}

The consequences of corruption have attracted much attention in recent years by both academics and policy makers.

In spite of the general perception that corruption have a negative impact on economic growth, one of the first studies about corruption (Leff, 1964) argued that corruption may "grease the wheels" of public activities, making individuals to avoid bureaucratic delay, especially in countries where bureaucratic regulations are cumbersome, and government employees to work harder if they receive bribe. This is why Leff asserts that corruption improves social welfare. Leys (Leys, 1965) and Huntington(Huntington, 1968) also support the idea that corruption has positive impact on economic growth because it increase the efficiency especially in the public sector. Lui developed an equilibrium queuing model of bribery in which the decision makings on bribe payments are decentralized to the customers (Lui, 1985). Based on this, Lui proved that, under some specified conditions, the bribing model is capable of giving socially optimal solutions. Lui argued that sometimes, the privately optimal speed of service chosen by the server may be faster than the speed without bribery. Acemoglu and Verdier, based on the case of an economy where contracts are necessary to encourage investments, finds that it may be optimal to allow some corruption and not enforce property rights fully(Acemoglu and Verdier, 1998). Another finding of Acemoglu and Verdier is that less developed economies may choose lower levels of property right enforcement and more corruption as a way to encourage development.

The second series of studies suggest that corruption doesn't improve efficiency.

First in this line is Myrdal (Myrdal, 1968), who argued that bureaucrats may deliberately delay to solve the problems so as to attract more bribes. This point of view is sustained more recently by a large number of empirical studies, based mainly on indices of corruption that are subjective assessments of the level of corruption, which suggest that corruption has negative effects on the economic and social development.

Most of the empirical studies of the impact of corruption have explored the efficiency implications of corruption through its impact on growth and investment, on composition of government expenditure and on allocation of foreign direct investment

First empirical study that explored the impact of corruption on growth and investment was conduced by Mauro, who used a sample of 67 countries and finds that corruption is negatively linked to the level of investment and economic growth, because the incentive to invest of the businessmen tend to diminish and so, the private investments will slow down (Mauro, 1995). In a newer study, that presented two models that rely on strategic complementarities to obtain multiple equilibrium, Mauro showed that the link between widespread corruption and low economic growth is explained by the behaviour of the individuals regarding public affairs and the behaviour of the politicians in a corrupt society (Mauro, 2002). Tanzi and Davoodi find that countries with higher perceived corruption tend to have lower real per capita GDP and countries with lower perceived corruption tend to have higher real per capita GDP. Another finding is that there is a negative association between corruption perception indexes and economic growth measured by growth in real per capita GDP (Tanzi and Davoodi, 2000).

On the other hand, Pelegrini and Gerlagh (2004) find that the indirect transmission channels are the significant one in explaining the negative effect of corruption on growth rates, so the conclusion is that once other relevant factors are controlled, corruption is insignificant with respect to growth in GDP per capita (Pelegrini and Gerlagh, 2004). On the contrary, Everhart et al. (2009) suggest that the impact of corruption on the level of public investment is not significant, but the interaction between corruption and public investment implies a reduction in private investment (Everhart et al., 2009). In a recent study, Aidt (2009) doesn't find convincing and robust evidence that corruption may have a significant negative effect on the growth rate of GDP per capita, but the paper suggests that corruption is a significant hindrance for sustainable development (Aidt, 2009). 
Also, there are studies that show the impact of corruption on public finance and on the public sector functions.

In this sense, Shleifer and Vishny find that corruption can reduce government revenue and lower the level of government output and services, including the provision and financing of health care and education services (Shleifer and Vishny, 1993). This idea is sustained by Erlich and Lui, ho find that corruption can reduce investment in human capital (Erlich and Lui, 1999). Not only the quantity of the services is affected, but also the quality of publicly provided services seems to lower, according to Bearse, Glomm and Janeba (Bearse et al., 2000).

Based on the data for a group of 39 sub-Saharan African countries during 1985-96, Ghura (1998) highlights that the variations in tax revenue-GDP ratios rise with declining inflation, implementation of structural reforms, rising human capital (a proxy for the provision of public services by the government) and declining corruption. So, the factors that affect tax revenue-GDP ratios are economic policies and the level of corruption. Tanzi and Davoodi also determined the impact on public finance and found that corruption not only tends to increase the size of public investment, but also skews the composition of public expenditures away from needed operation and maintenance towards expenditure on new equipment and reduces the productivity of public investment and cause the deterioration of a country's infrastructure and by this reduce private productivity. On the income side of the budget, corruption may reduce tax revenue because it compromises the government's ability to collect taxes and tariffs (Tanzi and Davoodi, 1997). Mauro (1998a, 1998b) presented evidence which suggests that corruption reduces public expenditures from growth-promoting areas (e.g., health and education) and stimulate other types of project (e.g., infrastructure investment) that are less productivity-enhancing, but which offer public servants better opportunities to collect bribes. In the same direction, an IRIS Center study for the World Bank (Azfar et. al., 2001) demonstrates that corruption can lead to negative effects on health care services and health outcomes(strongly emphasized in the Philippines case), but also on education outcomes resulting from reduced public sector services in those areas. In a more recent work, Azfar and Gurgur find that corruption reduces the outcomes of the public health services, but also have a negative effect on education outcomes (Azfar and Gurgur, 2008). In the same article, Azfar and Gurgur find that corruption affects public services in rural areas in different ways than urban areas, and that corruption harms the poor more than the wealthy. Also, in a series of studies coordinated by DiTella and Savedoff it was shown how corruption undermines the efficacy of health care in Latin America (DiTella and Savedoff, 2001).

Based on a simple neoclassical growth model with a self-seeking and corrupt public sector, Barreto and Alm finds that, holding the relative size of government constant, the presence of corruption distorts the country's tax structure, in a manner that countries affected by corruption relies more on consumption taxes than income taxes (Barreto and Alm, 2003). Another finding of this study is that the optimal size of government is smaller in an economy with corruption than in one without corruption, the explanation being the negative effects of corruption on social welfare via the implied loss in production of the public consumption and production goods when corruption occurs, effects that are no longer present in a clean economy. Attila integrates corruption in an endogenous growth model in two ways: corruption in public spending and corruption in taxation and finds that, under certain conditions, corruption can positively affect the rate of growth, but the second effect of corruption, and the more devastating one, is that it has a negative impact on growth by the tendency to make sub-optimal tax rate that maximizes the rate of growth in the long term and by creation of distortions leading to excessive tax rates harmful to growth (Attila, 2008). Cerqueti and Coppier demonstrate that the relationship between the tax rate and tax collection depends on the relevance of the "shame effect", meaning the possibility of the entrepreneur being detected and reported in a corrupt transaction (Cerqueti and Coppier, 2009). The authors find that in countries with a "low shame" effect, tax revenues grow as the tax rate increases. Moreover, there is a critical tax rate where the growth rate of tax revenues begins to reduce. In countries with a high "shame 
effect" tax revenues increase up to a threshold value and then decrease. As a policy implication, an optimal level of taxation exists both for "high shame" and "low shame" countries, which permits governments to maximize fiscal revenues, but the action that has to be taken are different.

Another important category of studies regards the impact of corruption on inequality and poverty. In this sense, Hendriks et al. (1999), Li et al. (2000), Gupta et. al. (2002) argue that corruption increases income inequality. Gupta et al. (2002) found further evidence that corruption increases inequality in education and land distribution.

Most of the econometric results reviewed point in the direction show that corruption is bad for economic growth, and also bad for a number of economic factors that tend to be correlated with growth: domestic investment, the quantity and composition of foreign direct investment, government expenditure on health and education, the quantity and quality of government investment in infrastructure, and generally the returns to business and trade. These factors are influencing social welfare, so the question is if the presence of corruption tends to reduce social welfare. The study intends to verify if there is a correlation between corruption and social welfare, viewed from the perspective of Sen's work on capabilities.

Base on whole theoretical acquisition, we assume the hypotheses:

$H$ : The level of social welfare is growing as the intensity of corruption is decreasing.

In summary, the meanings of the hypothesis's work relations are:

The sense (,the sings") of the hypothesis's work relation

\begin{tabular}{|c|c|}
\hline The trend of social welfare level & The trend of corruption \\
\hline+ & - \\
- & + \\
\hline
\end{tabular}

Table no. 1

g correlation, by contrary direction.

\section{Methods and results}

To quantify and to analyze the relationship between social welfare (dependent variable) and corruption (independent variable), we have considered the period 1996-2008 and a sample of 27 countries of European Union, with different degrees of economic development and politicaladministrative structures. The countries are: Belgium, France, Germany, Italy, Luxembourg, Netherlands, Denmark, Ireland, United Kingdom, Greece, Portugal, Spain, Austria, Finland, Sweden, Cyprus, Estonia, Latvia, Lithuania, Malta, Poland, Czech Republic, Slovakia, Slovenia, Hungary, Romania and Bulgaria.

1. Social welfare (HDI) is quantified by the "Human Development Index" which measures the degree of human development by combining life expectancy, education levels and realized income, on a scale from 0 to 1 , where 0 denotes a minimum level of welfare and 1 a maximum one.

2. Intensity of corruption (FC) is quantified by the "Freedom from corruption" which is the component of the Index of Economic Freedom, developed by The Heritage Foundation, on a scale from 0 to 100, where 0 indicates a very high level of corruption and 100 an extremely small one.

Based on the illustrated variables, the sense of changes existing between HDI and FC, in according with theoretical assumption made above, is as follows:

Table no. 2

The expected sense (,the sings”) of the relation between HDI - FC, according to working hypothesis

\begin{tabular}{|c|c|}
\hline The trend of HDI & The trend of FC \\
\hline+ & + \\
- & - \\
\hline
\end{tabular}


The method of analysis used is the econometrical modeling (with software EViews 6.0), elaborating a "Pool Date", regressive model, with this shape:

$$
Y_{i t}=\alpha+\beta x X_{i t}+\lambda_{t}+v_{i j}
$$

where $Y_{i t}$ represents the dependent variable - HDI, $\alpha$ intercept term, $\beta$ independent variables coefficients, $\mathrm{X}_{\mathrm{it}}$ independent variable $-\mathrm{FC}, \lambda_{\mathrm{t}}$ time-varying intercept (captures all of the variable that affect $Y_{i t}$ and that vary over time and cross-sectionally), $v_{i j}$ the remainder disturbance (capturing everything that is left unexplained about $\mathrm{Y}_{\mathrm{it}}$ ), $i$ cross-sectional units observed for dated periods - (the number of states - 27) and $t$ the period of time (years 1996-2008).

The econometric analysis has two steps:

a. The econometric tests of the ,pool”;

b. The "unit root test" of the residuals.

a. The econometric tests of the ,pool data" are presented in Tables no. 3.

Table no. 3

The econometric tests of the ,pool data" model HDI - FC in U.E.27's case

Dependent Variable: HDI?

Method: Pooled EGLS (Period SUR)

Sample: 19962008

Included observations: 13

Cross-sections included: 27

Total pool (balanced) observations: 351

Linear estimation after one-step weighting matrix

\begin{tabular}{|ccccc|}
\hline \hline Variable & Coefficient & Std. Error & t-Statistic & Prob. \\
\hline \hline BELGIUM--FCBELGIUM & 0.013179 & 0.000285 & 46.31743 & 0.0000 \\
FRANCE--FCFRANCE & 0.013083 & 0.000283 & 46.28539 & 0.0000 \\
GERMANY--FCGERMANY & 0.011528 & 0.000252 & 45.68250 & 0.0000 \\
ITALY--FCITALY & 0.017704 & 0.000389 & 45.54637 & 0.0000 \\
LUXEMBOURG-- & & & & \\
FCLUXEMBOURG & 0.010569 & 0.000230 & 45.91205 & 0.0000 \\
NETHERLANDS-- & & & & \\
FCNETHERLANDS & 0.010863 & 0.000234 & 46.45046 & 0.0000 \\
DENMARK--FCDENMARK & 0.009850 & 0.000213 & 46.17317 & 0.0000 \\
IRELAND--FCIRELAND & 0.012561 & 0.000274 & 45.92223 & 0.0000 \\
UK--FCUK & 0.010742 & 0.000232 & 46.22082 & 0.0000 \\
GREECE--FCGREECE & 0.019823 & 0.000446 & 44.48529 & 0.0000 \\
PORTUGAL--FCPORTUGAL & 0.013784 & 0.000312 & 44.22934 & 0.0000 \\
SPAIN--FCSPAIN & 0.015020 & 0.000327 & 45.98501 & 0.0000 \\
AUSTRIA--FCAUSTRIA & 0.011487 & 0.000249 & 46.19148 & 0.0000 \\
FINLAND--FCFINLAND & 0.009912 & 0.000214 & 46.33344 & 0.0000 \\
SWEDEN--FCSWEDEN & 0.010298 & 0.000220 & 46.86137 & 0.0000 \\
CYPRUS--FCCYPRUS & 0.015765 & 0.000361 & 43.73105 & 0.0000 \\
ESTONIA--FCESTONIA & 0.013505 & 0.000331 & 40.85200 & 0.0000 \\
LATVIA--FCLATVIA & 0.020993 & 0.000522 & 40.18858 & 0.0000 \\
LITHUANIA--FCLITHUANIA & 0.020589 & 0.000504 & 40.87203 & 0.0000
\end{tabular}

\footnotetext{
${ }^{3}$ For econometric model we used the econometric software Eviews 5.0.
} 


\begin{tabular}{|lllll|}
\hline MALTA--FCMALTA & 0.018752 & 0.000438 & 42.78048 & 0.0000 \\
POLAND--FCPOLAND & 0.018174 & 0.000435 & 41.77663 & 0.0000 \\
CZECHR--FCCZECHR & 0.018709 & 0.000436 & 42.93261 & 0.0000 \\
SLOVAKIA--FCSLOVAKIA & 0.047514 & 0.000451 & 105.3411 & 0.0000 \\
SLOVENIA--FCSLOVENIA & 0.016336 & 0.000373 & 43.80734 & 0.0000 \\
HUNGARY--FCHUNGARY & 0.016982 & 0.000406 & 41.80112 & 0.0000 \\
ROMANIA--FCROMANIA & 0.024753 & 0.000639 & 38.73689 & 0.0000 \\
BULGARIA--FCBULGARIA & 0.022355 & 0.000564 & 39.62554 & 0.0000 \\
\hline \hline & Weighted Statistics & \\
\hline \hline R-squared & 0.913509 & Mean dependent var & 9.657922 \\
Adjusted R-squared & 0.906568 & S.D. dependent var & 9.154091 \\
S.E. of regression & 1.011230 & Sum squared resid & 331.3182 \\
Durbin-Watson stat & 2.129130 & & \\
\hline \hline
\end{tabular}

The tests of the model show the following:

- the absolute values of the standard errors corresponding to the coefficients of the function are lower than the values of the coefficients, witch sustains the correct estimation of these coefficients (a conclusion reinforced by the low values of the probabilities);

- the value of the correlation coefficient, shows a very significant statistical correlation between the dependent variable - HDI and the independent variable - FC (the changes in the FC are reflected in proportion by $91.35 \%$ in the changes HDI);

- the Durbin-Watson test (with a resulting value near to critical level 2) shows that the residual variables are very low autocorrelated.

More, for a better estimation, we have corrected both period heteroskedasticity and general correlation of observations within a given cross-section. Moreover, to obtain the robust coefficient standard errors we have applied the Period SUR (PCSE) method.

b. The "unit root test" of the residuals. For verifying the stationarity of the residuals are used the ,unit root tests” proposes by Levin, Lin \& Chu, Im, Pesaran \& Shin W-stat, ADF and PP. The results are illustrated in Table no. 4. 
Table no.4

The "unit root test" of the residuals

\begin{tabular}{|c|c|c|c|c|}
\hline \multicolumn{5}{|c|}{$\begin{array}{l}\text { Sample: } 19962008 \\
\text { Exogenous variables: Individual effects } \\
\text { Automatic selection of maximum lags } \\
\text { Automatic selection of lags based on SIC: } 0 \text { to } 2 \\
\text { Newey-West bandwidth selection using Bartlett kernel }\end{array}$} \\
\hline Method & Statistic & Prob. $* *$ & $\begin{array}{l}\text { Cross- } \\
\text { sections }\end{array}$ & Obs \\
\hline \multicolumn{5}{|c|}{ Null: Unit root (assumes common unit root process) } \\
\hline Levin, Lin \& Chu $\mathrm{t}^{*}$ & -10.5627 & 0.0000 & 27 & 310 \\
\hline \multicolumn{5}{|c|}{ Null: Unit root (assumes individual unit root process) } \\
\hline Im, Pesaran and Shin W-stat & -7.61896 & 0.0000 & 27 & 310 \\
\hline ADF - Fisher Chi-square & 155.218 & 0.0000 & 27 & 310 \\
\hline PP - Fisher Chi-square & 140.915 & 0.0000 & 27 & 324 \\
\hline
\end{tabular}

All tests indicate that the null hypothesis is rejected, meaning that the ,residuals of the cross-sectional group" is stationary - $\mathrm{I}(0)$.

In conclusion, the model could be considered representative to describe, at E.U.27's level, the connection between HDI and FC.

\section{Discussion}

The obtained results based on the constructed model show that corruption phenomena influence in a major extent social welfare. Utilizing the coefficients of independent variable, the descending ranking of countries regarding HDI's elasticity in relation with FC is showed in Table no. 5 .

Table no. 5

The ranking of U.E.27's countries regarding HDI's elasticity in relation with FC

\begin{tabular}{|c|c|c|}
\hline No. & Country & Level of coefficient \\
\hline 1 & Slovakia & 0.047514 \\
\hline 2 & Romania & 0.024753 \\
\hline 3 & Bulgaria & 0.022355 \\
\hline 4 & Latvia & 0.020993 \\
\hline 5 & Lithuania & 0.020589 \\
\hline 6 & Greece & 0.019823 \\
\hline 7 & Malta & 0.018752 \\
\hline 8 & Czechr & 0.018709 \\
\hline 9 & Poland & 0.018174 \\
\hline 10 & Italy & 0.017704 \\
\hline 11 & Hungary & 0.016982 \\
\hline 12 & Slovenia & 0.016336 \\
\hline 13 & Cyprus & 0.015765 \\
\hline
\end{tabular}




\begin{tabular}{|l|c|c|}
14 & Spain & 0.01502 \\
\hline 15 & Portugal & 0.013784 \\
\hline 16 & Estonia & 0.013505 \\
\hline 17 & Belgium & 0.013179 \\
\hline 18 & France & 0.013083 \\
\hline 19 & Ireland & 0.012561 \\
\hline 20 & Germany & 0.011528 \\
\hline 21 & Austria & 0.011487 \\
\hline 22 & Netherlands & 0.010863 \\
\hline 23 & Uk & 0.010742 \\
\hline 24 & Luxembourg & 0.010569 \\
\hline 25 & Sweden & 0.010298 \\
\hline 26 & Finland & 0.009912 \\
\hline 27 & Denmark & 0.00985 \\
\hline
\end{tabular}

The results confirm the proposed theoretical hypotheses, following the idea that the limitation of corruption's phenomena (maximizing FC index) has the result of increasing of social welfare (maximizing HDI index).

\section{Conclusions}

As a complex phenomenon, the corruption hits the entire world, regardless of the geographical location, population, level of economic development, political regime or type of government.

Based on our paper' results, we find that corruption has a significant negative impact on the human well-being (measured by the Human Development Index, which combine the economical aspects with some of the most important social ones: health care and education). This is a result of the direct consequences of corruption such as: lower growth, affecting resources' allocations from the public budgets, promoting inequality. The main results suggest that the corruption is a "key question" especially in developing and in transition economies, but the disturbance constant unobserved factors decrease the phenomenon and compensate the periodical negative unobserved factors.

In this sense, policies against corruption could be seen as measures for increasing well-being of the citizens.

\section{References}

1. Acemoglu, D., Verdier, T., 1998. Property Rights, Corruption and the Allocation of Talent: A General Equilibrium Approach, The Economic Journal, 108.

2. Aidt T., 2009. Corruption, institutions, and economic Development, Oxford Review of Economic Policy, Volume 25, Number 2

3. Attila G., 2008. Corruption, taxation and economic growth: theory and evidence, CERDICNRS Working Paper, available online at http://www.cerdi.org/uploads/ed/2008/2008.29.pdf

4. Azfar O., Gurgur T., 2008. Does corruption affect health outcomes in the Philippines?, Economics of Governance, Volume 9, Number 3

5. Azfar O., Kähkönen S., Meagher P., 2001. Conditions for Effective Decentralized Governance: A Synthesis of Research Findings, College Park, MD: IRIS Center, available online at http://www.iris.umd.edu/download.aspx?ID=b587c7e7-919f-46f1-b166$1297 \mathrm{ba} 15818 \mathrm{a}$ 
6. Barreto R. A., Alm J., 2003. Corruption, Optimal Taxation, And Growth, Public Finance Review, Vol. 31 No. 3, May 2003

7. Bearse P., Glomm G., Janeba E., 2000. Why poor countries rely mostly on redistribution inkind, Journal of Public Economics, vol. 75(march)

8. Cerqueti R., Coppie R., 2009. Tax revenues, fiscal corruption and "shame" costs, Economic Modelling, 26

9. DiTella R., Savedoff W. (eds), 2001. Diagnosis corruption: Fraud in Latin America's Public Hospitals, Inter American Development Bank, Washington, DC.

10. Egger P., Winner H., 2005. Evidence on Corruption as an Incentive for Foreign Direct Investment, European Journal of Political Economy, 21

11. Ehrlich I., Lui F.T., 1999. Bureaucratic corruption and endogenous economic growth, Journal of Political Economy, vol. 107

12. Everhart S., Martinez- Vazquez J., McNab R., 2009. Corruption, governance, investment and growth in emerging markets, Applied Economics, Volume 41, Issue 13

13. Ghura D., 1998. Tax Revenue in Sub-Saharan Africa: Effects of Economic Policies and Corruption, IMF Working Paper

14. Gupta S., Davoodi H. R., Tiongson E. R., 2000. Corruption and the Provision of Health Care and Education Services, IMF Working Paper

15. Gupta S., Davoodi H. R., Alonso-Terme R., 2002. Does Corruption Affect Income Inequality and Poverty?, Economics of Governance, 3(1)

16. Heidenheimer A. J. et al. (eds), 1993. Handbook of Political Corruption. New Brunswick: Transaction Publishers

17. Hendriks J., Keen M., Muthoo A., 1999. Corruption, extortion and evasion, Journal of Public Economics Volume 74, Issue 3

18. Hungtington S., 1968. Modernization and corruption, Political Order in Changing Societies. New Haven. Conn., Yale University Press

19. Leff N., 1964. Economic Development through Bureaucratic Corruption, American Behavioral Scientist, 8(3)

20. Leys C., 1970. What is the problem about corruption?, in Heidenheimer, A.J. (Ed.), Political Corruption: Readings in Comparative Analysis, Holt Reinehart, New York, NY.

21. Li H., Xu L. C., Zou, H., 2000. Corruption, income distribution and growth, Economics and Politics 12(2)

22. Lui F., 1985. An Equilibrium Queuing Model of Bribery, Journal of Political Economy, 93

23. Mauro P., 1995. Corruption and Growth, Quarterly Journal of Economics, 110

24. Mauro P., 1997. Why Worry About Corruption?, Economic issues, International Monetary Fund, Washington DC, available online at: http://www.jims-israel.org/pdf/IMF.pdf

25. Mauro P., 1998a. Corruption and Composition of Government Expenditure, Journal of Public Economics, 69

26. Mauro P., 1998b. Corruption: Causes, Consequences, and Agenda for Further Research, Journal of Finance and Development, Volume 35

27. Mauro P., 2002. The Persistence of Corruption and Slow Economic Growth, IMF Working Paper

28. Myrdal, G., 1968. Asian drama: An enquiry into the poverty of nations (Vol. 2), New York, The Twentieth Century Fund, reprint in Political corruption: A handbook, A. J. Heidenheimer, M. Johnston, V.T. LeVine (Eds.), Oxford, Transaction Books, 1989, pp. 953-961.

29. Mutaşcu, M. I., 2009. The Effect of the Government Intervention in Economy on Corruption, Eurasian Journal of Business and Economics, 2 (3)

30. Nye J., 1967. Corruption and Political Development: A Cost-Benefit Analysis, American Political Science Review vol. 61, No. 2 
31. Pellegrini L. Gerlagh R., 2004. Corruption's Effect on Growth and its Transmission Channels, Kyklos, Vol. 57, No. 3

32. Rose-Ackerman S., 1999. Corruption and Government: Causes, Consequences, and Reform, Cambridge, Cambridge University Press

33. Rose-Ackerman S., 1978. Corruption: A Study in Political Economy, Academic Press, New York

34. Shleifer, A., and Vishny, R. W., 1993. Corruption, Quarterly Journal of Economics, 108, 599-618.

35. Tanzi V., Davoodi H. R., 1997. Corruption, Public Investment, and Growth, IMF Working Paper

36. Tanzi V., 1998. Corruption Around the World, Causes, Consequences, Scope and Cures, IMF Staff Papers, 45(4)

37. Tanzi V., Davoodi H. R., 2000. Corruption, Growth and Public Finances, IMF Working Paper 